\title{
KEMAMPUAN MEMBACA KRITIS PESERTA DIDIK KELAS VIII SMP NEGERI 15 BANJARMASIN
}

\author{
THE ABILITY OF CRITICAL READING OF SMP 15 BANJARMASIN \\ STUDENTS AT GRADE EIGHTH
}

\author{
Sapiah; Jumadi; Ahsani Taqwiem \\ Program Studi Pendidikan Bahasa dan Sastra Indonesia \\ FKIP Universitas Lambung Mangkurat \\ piah334@gmail.com
}

\begin{abstract}
Abstrak
Tujuan penelitian, mendeskripsikan kemampuan, (a) mengingat dan mengenali fakta tersurat isi bacaan, (b) menginterpretasikan makna tersirat isi bacaan, (c) mengaplikasikan konsep isi bacaan, (d) menganalisis isi bacaan, (e) menyintesis isi bacaan, (f) menilai isi bacaan, dan (g) membaca kritis secara komprehensif peserta didik kelas VIII SMP Negeri 15 Banjarmasin. Jenis penelitian ini adalah penelitian kuantitatif dengan metode deskriptif. Pengambilan sampel menggunakan teknik sampling sederhana. Pangambilan sampel 25\% dari pupolasi, yakni sebanyak 52 orang. Teknik pengumpulan data melalui tes.Teknik analisis data dilakukan dengan beberapa tahapan. Berdasarkan analisis hasil penelitian, yaitu kemampuan (a) mengingat dan mengenali fakta tersurat kategori baik, dengan nilai rata-rata 66,15. (b) menginterpretasikan makna tersirat kategori cukup, dengan nilai rata-rata 65 . (c) mengaplikasikan konsep dikategorikan baik, dengan nilai rata-rata 66,53. (d) menganalisis dikategorikan baik, dengan nilai rata-rata 72,5. (e) menyintesis dikategorikan baik, dengan nilai rata-rata 75,19. (f) menilai isi bacaan, dikategorikan cukup, dengan nilai rata-rata 62,5. Untuk kemampuan membaca kritis secara komprehensif dikategorian baik, dengan nilai ratarata 70,10 .
\end{abstract}

Kata Kunci: kemampuan, membaca kritis

\begin{abstract}
Describe the ability, (a) remember and recognize the facts expressed in the contents of the reading, $(b)$ interpret the implicit meaning of the reading content, $(c)$ apply the concept of reading content, $(d)$ analyze the contents of the reading, $(e)$ synthesize the reading content, $(f)$ assessing the content of the reading, and $(g)$ comprehensively critical reading of class VIII students of SMP Negeri 15 Banjarmasin. This type of research is quantitative research with descriptive methods. Sampling uses a simple sampling technique. Sampling is 25\% from pupolation, which is as many as 52 people. The technique of collecting data through tests. Data analysis techniques are carried out in several stages. Based on the results of the analysis obtained the results of the study, namely the ability to $(a)$ remember and recognize explicit facts categorized as good, with an average value of 66.15. (b) interpreting the implicit meanings is categorized sufficiently, with an average value of 65. (c) applying the concept is categorized as good, with an average value of 66.53. (d) analyzing is categorized as good, with an average value of 72.5. (e) synthesizing is categorized as good, with an average value of 75.19. $(f)$ assessing the contents of the reading, categorized as sufficient, with an average value of 62.5. Comprehensive critical reading skills are categorized as good, with an average score of 70.10 .
\end{abstract}

Keywords: ability, critical reading 


\section{Pendahuluan}

Kemampuan berbahasa memiliki empat aspek kemampuan, diantaranya kemampuan membaca. Penelitian ini lebih menekankan pada kemampuan membaca.

Membaca kritis merupakan upaya memahami isi makna atau arti yang tersirat maupun tersurat di dalam buku atau bacaan. Kemampuan membaca kritis merupakan dasar kuat bagi peserta didik. Hal ini disebabkan, setiap proses kegiatan belajar mengajar membutuhkan suatu pemahaman, penganalisisan, dan meng-ungkapkan kembali permasalahan tersebut sesuai dengan pemahaman dan pengetahuan. Dengan demikian dari beberapa penelitian, dapat disimpulkan bahwa budaya membaca di Indonesia tergolong rendah. Jika budaya membaca rendah, tentu berdampak terhadap kemampuan membaca kritis.

Tujuan dari penelitian, yakni (a) untuk mendeskripsikan kemampuan mengingat dan mengenali fakta tersurat dalam isi bacaan. (b) mendeskripsikan kemampuan menginterpretasikan makna tersirat isi bacaan. (c) mendeskripsikan kemampuan mengaplikasikan konsep isi bacaan. (d) mendeskripsikan kemampuan menganalisis isi bacaan. (e) untuk mendeskripsikan kemampuan menyintesis isi bacaan. (f) untuk mendeskripsikan kemampuan menilai isi bacaan, dan (g) untuk mendeskripsikan kemampuan membaca kritis secara komprehensif.

\section{Metode Penelitian}

\section{Jenis Penelitian}

Jenis penelitian ini adalah deskriptif kuantitatif. Penelitian ini disebut kuantitatif karena data berupa angka. Metode deskriptif yang bertujuan untuk mendeskripsikan kemampuan membaca kritis peserta didik.

\section{Waktu dan Tempat Penelitian}

Penelitian dilaksanakan pada tanggal 6, 8, 16, dan 27 November 2018 di SMP Negeri 15 Banjarmasin

\section{Target atau Subjek Penelitian}

Populasi dalam penelitian ini seluruh peserta didik kelas VIII SMP Negeri 15 Banjarmasin, Penggambilan sampel dengan teknik sampling sederhana atau Berdasarkan pendapat Arikunto (1999: 134), jika populasi melebihi 100 maka pengambilan sampel diambil $20 \%-25 \%$ dari populasi. Karena populasi melebihi 100, yaitu 210, maka diambil sampel $25 \%$ dari populasi. Oleh karena itu, sampel 52 orang, meliputi kelas kelas VIII A dan VIII C mewakili populasi penelitian.

\section{Prosedur}

Prosedur pemerolehan data dilakukan melalui tahapan, mengujicobakan soal kemampuan membaca kritis, memberikan tes kemampuan membaca kritis. 
Data, Instrumen, dan Teknik Pengumpulan Data

Pemerolehan data dari tes kemampuan membaca kritis. Sumber data diperoleh dari peserta didik.

Instrumen penelitian meliputi, hasil tes, serta hasil rekaman kegiatan berupa foto-foto saat penelitian dilaksanakan, agar penelitian lebih akurat. Syarat validitas dan reliabilitas dalam artian tes tersebut harus tepat dan tetap, untuk itu tes diuji kevalidannya dan reliabilitasnya. Valid item

Untuk mengetahui valid atau tidaknya tes digunakan validitas item. Menggunakan rumus Rpbi rumusnya sebagai berikut.

$$
\text { Rpbi }=\frac{M \rho-M t}{S t} \sqrt{\frac{p}{q}}
$$

Reliabilitas

Reliabilitas dipakai untuk menghitung tes pilihan ganda yang sudah diuji validitasnya. Rumus reliabilitas yang dipakai, yaitu rumus metode belah dua. Dengan rumus berikut:

$$
\mathrm{r} 11=\frac{2 r^{1 / 2} 1 / 2}{\left(1+r^{1 / 2} 1 / 2\right)}
$$

Adapun teknik umtuk mengumpulkan data dengan tes. Tes yang diberikan adalah tes objektif. Soal pilihan ganda dipilih sebagai tes untuk mengukur kemampuan membaca kritis peserta didik.

\section{Teknik Analisis Data}

Teknik analisis data dilakukan dengan cara, yaitu melakukan pemeriksaan hasil tes kemampuan membaca kritis dan memberikan skor 0 untuk salah dan 1 untuk benar, menganalisis kemampuan membaca kritis per indikator, menganalisis kemampuan membaca kritis secara keseluruhan, mengubah skor menjadi nilai, dan menghitung nilai rata-rata.

Skala penilaian yang digunakan, mengacu pada skala penilaian yang dibuat Arikunto (1999: 245) sebagai berikut.

Tabel 6 Skala Penilaian

\begin{tabular}{|c|c|}
\hline $\begin{array}{c}\text { Interval } \\
\text { penguasaan }\end{array}$ & Keterangan \\
\hline $80-100$ & Baik Sekali \\
\hline $66-79$ & Baik \\
\hline $56-65$ & Cukup \\
\hline $40-55$ & Kurang \\
\hline $0-39$ & Gagal \\
\hline
\end{tabular}

\section{Hasil dan Pembahasan}

\section{Analisis Data}

Data dikumpulkan 2 kali pertemuan, pertemuan pertama untuk mengujicobakan instrumen pada tanggal 6 November 2018 di kelas VIII C dan 8 November 2018 di Kelas VIII A. Pertemuan kedua dilaksanakan pengumpulan data sebagai hasil penelitian pada tanggal 16 November di kelas VIII A dan 27 November 2018 di kelas VIII C. 
Analisis perindikator. Kemudian, menganalisis kemampuan membaca kritis peserta didik kelas VIII SMP Negeri 15 Banjarmasin secara komprehensif. Selanjutnya mendeskripsikan hasil analisis. Analisis data dikualifikasikan sesuai pedoman yang dipakai, yakni skala penilaian yang dibuat Arikunto.

\section{a. Kemampuan Mengingat dan}

\section{Mengenali Fakta Tersurat Isi}

\section{Bacaan (Indikator 1)}

Hasil kemampuan mengingat dan mengenali fakta tersurat isi bacaan, dapat dikualifikasikan pada tabel berikut.

\section{Tabel 7}

\section{Pengklasifikasian Indikator 1}

\begin{tabular}{|c|c|c|c|}
\hline $\begin{array}{c}\text { Interval } \\
\text { penguasaan }\end{array}$ & Keterangan & Frekuensi & Persentase \\
\hline $80-100$ & Baik Sekali & 19 & $36,54 \%$ \\
\hline $66-79$ & Baik & 6 & $11,54 \%$ \\
\hline $56-65$ & Cukup & 15 & $28,85 \%$ \\
\hline $40-55$ & Kurang & 8 & $15,39 \%$ \\
\hline $0-39$ & Gagal & 4 & $7,69 \%$ \\
\hline \multicolumn{2}{|c|}{ Total } & 52 & $100 \%$ \\
\hline
\end{tabular}

Total keseluruhan nilai indikator 1 , yaitu 3.440. Perolehan nilai tersebut akan dicari nilai rata-rata untuk mengetahui kategori kemampuan membaca kritis indikator 1.

$X=\frac{\Sigma X}{N} \quad X=\frac{3.440}{52}=66,15$

Dari hasil perhitungan nilai rata $\mathbf{6 6 , 1 5}$. Berdasarkan nilai tersebut dapat disimpulkan bahwa kemampuan mengingat dan mengenali fakta tersurat isi bacaan (indikator 1) tergolong baik pada interval penguasaan 66-79

\section{b. Kemampuan Menginterpretasikan}

\section{Makna Tersirat Isi Bacaan} (Indikator 2)

Hasil kemampuan menginterpretasikan makna tersirat isi bacaan, dapat dikualifikasikan pada tabel berikut.

Tabel 8

\section{Pengklasifikasian Indikator 2}

\begin{tabular}{|c|c|c|c|}
\hline $\begin{array}{c}\text { Interval } \\
\text { penguasaan }\end{array}$ & Keterangan & Frekuensi & Persentase \\
\hline $80-100$ & Baik Sekali & 19 & $36,54 \%$ \\
\hline $66-79$ & Baik & 8 & $15,39 \%$ \\
\hline $56-65$ & Cukup & 11 & $21,15 \%$ \\
\hline $40-55$ & Kurang & 9 & $17,31 \%$ \\
\hline $0-39$ & Gagal & 5 & $9,61 \%$ \\
\hline \multicolumn{2}{|c|}{ Total } & 52 & $100 \%$ \\
\hline
\end{tabular}

Total keseluruhan nilai indikator 2, yaitu

3.380. Perolehan nilai tersebut akan dicari nilai rata-rata untuk mengetahui kategori kemampuan membaca kritis indikator 2.

$$
X=\frac{\Sigma X}{N} \quad X=\frac{3.380}{52}=65
$$

Perolehan nilai rata 65. Berdasarkan nilai rata-rata dapat disimpulkan bahwa kemam-puan menginterpretasikan makna tersirat isi bacaan (indikator 2) tergolong cukup pada interval penguasaan 56-65.

\section{c. Kemampuan Mengaplikasikan \\ Kon-sep Isi Bacaan (Indikator 3) \\ Hasil kemampuan mengaplikasikan konsep isi bacaan, dapat dikualifikasikan pada tabel berikut.}


Tabel 9

Pengklasifikasian Indikator 3

\begin{tabular}{|c|c|c|c|}
\hline $\begin{array}{c}\text { Interval } \\
\text { penguasaan }\end{array}$ & Keterangan & Frekuensi & Persentase \\
\hline $80-100$ & Baik Sekali & 23 & $44,23 \%$ \\
\hline $66-79$ & Baik & 7 & $13,46 \%$ \\
\hline $56-65$ & Cukup & 8 & $15,39 \%$ \\
\hline $40-55$ & Kurang & 9 & $17,31 \%$ \\
\hline $0-39$ & Gagal & 5 & $9,61 \%$ \\
\hline \multicolumn{2}{|c|}{ Total } & 52 & $100 \%$ \\
\hline
\end{tabular}

Total keseluruhan nilai indikator 3, yaitu 3.460. Perolehan nilai tersebut akan dicari nilai rata-rata untuk mengetahui kategori kemampuan membaca kritis indikator 3.

$X=\frac{\Sigma X}{N} \quad X=\frac{3.460}{52}=66,53$

Perolehan nilai rata $\mathbf{6 6 , 5 3}$. Berdasarkan nilai rata-rata dapat disimpulkan bahwa kemampuan mengaplikasikan konsep isi bacaan (indikator 3) tergolong baik diinterval penguasaan 66-79.

\section{d. Kemampuan Menganalisis Isi Bacaan (Indikator 4)}

Hasil kemampuan menganalisis isi bacaan, dapat dikualifikasikan pada tabel berikut.

Tabel 10

\section{Pengklasifikasian Indikator 4}

\begin{tabular}{|c|c|c|c|}
\hline $\begin{array}{c}\text { Interval } \\
\text { penguasaan }\end{array}$ & Keterangan & Frekuensi & Persentase \\
\hline $80-100$ & Baik Sekali & 27 & $51,93 \%$ \\
\hline $66-79$ & Baik & 11 & $21,15 \%$ \\
\hline $56-65$ & Cukup & 3 & $5,77 \%$ \\
\hline $40-55$ & Kurang & 7 & $13,46 \%$ \\
\hline $0-39$ & Gagal & 4 & $7,69 \%$ \\
\hline \multicolumn{2}{|c|}{ Total } & 52 & $100 \%$ \\
\hline
\end{tabular}

Total keseluruhan nilai indikator 4, yaitu 3.770. Perolehan nilai tersebut akan dicari nilai rata-rata untuk mengetahui kategori kemampuan membaca kritis indikator 4.

$X=\frac{\Sigma X}{N} \quad X=\frac{3.770}{52}=72,5$

Perolehan nilai rata $\mathbf{7 2 , 5}$. Berdasarkan nilai rata-rata dapat disimpulkan bahwa kemampuan menganalisis isi bacaan (indikator 4) tergolong baik diinterval penguasaan 6679.

\section{e. Kemampuan Menyintesis Isi \\ Bacaan (Indikator 5)}

Hasil kemampuan menyintesis isi bacaan, dapat dikualifikasikan pada tabel berikut.

Tabel 11

Pengklasifikasian Indikator 5

\begin{tabular}{|c|c|c|c|}
\hline $\begin{array}{c}\text { Interval } \\
\text { penguasaan }\end{array}$ & Keterangan & Frekuensi & Persentase \\
\hline $80-100$ & baik Sekali & 28 & $53,85 \%$ \\
\hline $66-79$ & Baik & 12 & $23,08 \%$ \\
\hline $56-65$ & Cukup & 3 & $5,77 \%$ \\
\hline $40-55$ & Kurang & 7 & $13,46 \%$ \\
\hline $0-39$ & Gagal & 2 & $3,84 \%$ \\
\hline \multicolumn{2}{|c|}{0} & 52 & $100 \%$ \\
\hline
\end{tabular}

Total keseluruhan nilai indikator 5, yaitu

3.910. Perolehan nilai tersebut akan dicari nilai rata-rata untuk mengetahui kategori kemampuan membaca kritis indikator 5.

$X=\frac{\Sigma X}{N}$

$X=\frac{3.910}{52}=75,19$ 
Perolehan nilai rata75,19.

Berdasarkan nilai rata-rata dapat disimpulkan bahwa kemampuan menyintesis isi bacaan (indikator 5) tergolong baik diintervalpenguasaan 6679.

\section{f. Kemampuan Menilai Isi Bacaan (Indikator 6)}

Hasil kemampuan menilai isi bacaan, dapat dikualifikasikan pada tabel berikut.

Tabel 12

\section{Pengklasifikasian Indikator 6}

\begin{tabular}{|c|c|c|c|}
\hline $\begin{array}{c}\text { Interval } \\
\text { penguasaan }\end{array}$ & Keterangan & Frekuensi & Persentase \\
\hline $80-100$ & Baik Sekali & 16 & $30,77 \%$ \\
\hline $66-79$ & Baik & 13 & $25 \%$ \\
\hline $56-65$ & Cukup & 5 & $9,61 \%$ \\
\hline $40-55$ & Kurang & 9 & $17,31 \%$ \\
\hline $0-39$ & Gagal & 9 & $17,31 \%$ \\
\hline \multicolumn{2}{|c|}{ Total } & 52 & $100 \%$ \\
\hline
\end{tabular}

Total keseluruhan nilai indikator 6 , yaitu 3.250. Perolehan nilai tersebut akan dicari nilai rata-rata untuk mengetahui kategori kemampuan membaca kritis indikator 6.

$X=\frac{\Sigma X}{N} \quad X=\frac{3.250}{52}=62,5$

Perolehan nilai rata $\mathbf{6 2 , 5}$.

Berdasarkan nilai rata-rata dapat disimpulkan bahwa kemampuan menilai isi bacaan (indikator 6) tergolong cukup diintervalpenguasaan 56-65. g. Kemampuan Membaca Kritis

Peserta Didik Kelas VIII SMP

Negeri 15 Banjarmasin Secara

\section{Komprehensif}

Analisis yang dilakukan untuk mengetahui kemampuan membaca kritis peserta didik kelas VIII SMP Negeri 15 Banjarmasin secara komprehensif, akan dilakukan sama halnya dengan analisis perindikator sebelumnya. Hasil kemampuan membaca kritis secara komprehensif, dapat dikualifikasikan pada tabel berikut.

Tabel 13

\section{Pengklasifikasian Kemampuan Membaca} Kritis Komprehensif

\begin{tabular}{|c|c|c|c|}
\hline $\begin{array}{c}\text { Interval } \\
\text { penguasaan }\end{array}$ & Keterangan & Frekuensi & Persentase \\
\hline $80-100$ & Baik Sekali & 18 & $34,61 \%$ \\
\hline $66-79$ & Baik & 16 & $30,77 \%$ \\
\hline $56-65$ & Cukup & 4 & $7,69 \%$ \\
\hline $40-55$ & Kurang & 11 & $21,15 \%$ \\
\hline $0-39$ & Gagal & 3 & $5,77 \%$ \\
\hline \multicolumn{2}{|c|}{ Total } & 52 & $100 \%$ \\
\hline
\end{tabular}

Penjelaskan hasil kemampuan mem-baca kritis secara komprehensif, dikelompokkan menjadi lima kategori, dengan penjelasan dari kategori terendah sebagai berikut. Kategori pertama, peserta didik yang menduduki kualifikasi gagal pada interval penguasaan 0-39 sebanyak 3 orang dengan persentase $5,77 \%$. Kedua, sebanyak 11 orang dengan persentase 21,15\% menduduki kualifikasi kurang pada interval penguasaan 40-55. Ketiga, 4 orang pe-serta didik dengan persentase 
7,69\% mempunyai kualifikasi cukup pada interval penguasaan 56-65. Keempat, dengan kualifikasi baik pada interval penguasaan 66-79 sebanyak 16 orang dengan persentase $30,77 \%$. Kelima, kualifikasi tertinggi, yaitu baik sekali pada interval penguasaan $80-100$ diperoleh sebanyak 18 orang peserta didik dengan persentase $34,61 \%$.

Total keseluruhan nilai kemampuan membaca kritis secara komprehensif, yaitu 3.645,5. Perolehan nilai tersebut akan dicari nilai rata-rata untuk mengetahui kategori kemampuan membaca kritis secara komprehensif.

$$
X=\frac{\Sigma X}{N} \quad X=\frac{3.645,5}{52}=70,10
$$

Perolehan nilai rata $\mathbf{7 0 , 1 0 .}$ Berdasarkan nilai rata-rata dapat disimpulkan bahwa kemampuan membaca kritis secara komprehensif tergolong baik diintervalpenguasaan 66 79.

\section{Pembahasan}

Nurhadi (2010: 145-180) mengemukakan enam aspek yang harus dikuasai pembaca kritis, yaitu (a) mengingat dan mengenali fakta tersurat isi bacaan, (b) menginterpretasikan makna tersirat isi bacaan, (c) mengaplikasikan konsep isi bacaan, (d) menganalisis isi bacaan, (e) menyintesis isi bacaan, dan (f) menilai isi bacaan.
Dari hasil analisis data, enam aspek atau yang menjadi indikator kemampuan membaca kritis, perhitungan nilai ratarata setiap indikator diperoleh dua indikator menduduki kategori cukup, dan empat lainnya pada kategori baik. Indikator yang menduduki kategori cukup pada interval penguasaan 56-65, yaitu indikator kemampuan menginterpretasikan makna tersirat isi bacaan (indikator 2) dengan nilai rata-rata 65 dan kemampuan menilai isi bacaan (indikator 6) dengan nilai rata-rata 62,5. Selanjutnya, empat indikator pada interval penguasaan 66-79 dengan kategori baik. Pertama, kemampuan mengingat dan mengenali fakta tersurat isi bacaan (indikator 1) dengan nilai rata-rata 66,15. Kedua, kemampuan mengaplikasikan konsep isi bacaan (indikator 3) dengan nilai rata-rata 66,53. Ketiga, kemampuan menganalisis isi bacaan (indikator 4) dengan nilai rata-rata 72,5. Keempat, kemampuan menyintesis isi bacaan (indikator 5) dengan nilai rata-rata 75,19. Kemampuan membaca kritis peserta didik secara komprehensif masuk dalam lima kategori yang dibuat Arikunto, yaitu gagal, kurang, cukup, baik dan baik sekali. Namun, hasil dari nilai rata-rata secara keseluruhan menduduki interval penguasaan 66-79 dan tergolong baik dengan nilai rata-rata 70,10. 
Berdasarkan tabel 13, sebanyak 3 orang kategori gagal dengan persentase $5,77 \%$. Peserta didik yang dikategorikan gagal, jelas tidak memenuhi keseluruhan aspek membaca kritis, dari 60 butir soal membaca kritis, peserta didik hanya mampu menjawab dengan benar kurang dari 20 butir soal dan dibuktikan dibeberapa indikator, 3 orang peserta didik ini yang nilainya paling rendah, bahkan hanya bisa menjawab 1 soal yang benar di salah satu indikator.

Sebanyak 11 orang kategori kurang dengan persentase 21,15\%. Dari 60 butir soal hanya mampu menjawab antara 24 sampai 33 butir soal dengan benar. Meskipun, dibeberapa indikator memperoleh skor lebih dari 7 namun jika ditotalkan keseluruhan, peserta didik yang menduduki posisi ini memperoleh nilai di bawah 56 dan dikategorikan kurang.

Sebanyak 4 orang peserta didik menduduki kategori cukup dengan persentase $7,69 \%$. Peserta didik yang berada pada kategori ini memperoleh nilai antara 56,7 sampai 65 dengan menjawab soal yang benar sebanyak 34 sampai 39. Sama hal dengan sebelumnya, meskipun dibeberapa indikator, nilai yang diperoleh cukup tinggi. Namun, secara keseluruhan masih berada pada kategori cukup karena yang jadi patokan merupakan nilai gabungan keseluruhan indikator.

16 orang kategori baik dengan persentase $30,77 \%$. Peserta didik yang menduduki posisi ini tentunya peserta didik yang secara keseluruhan menjawab 40 sampai 47 butir soal dengan benar dan masing-masing soal indikator dijawab minimal 7 butir soal yang benar. Sehingga, bisa menduduki kategori ini.

Kategori teratas, yakni baik sekali diperoleh 18 orang peserta didik dengan persentase $34,61 \%$. Peserta didik yang menduduki posisi ini, tentunya memenuhi keenam aspek membaca kritis dengan sangat baik, dengan skor minimal perindikator 8 dan keseluruhan 48 dan memperoleh nilai minimal 80. Namun, dari 18 orang yang berada pada posisi ini, ada 3 orang yang nilainya paling tinggi dari 49 peserta didik lainnya dengan menjawab 52 butir soal benar dengan perolehan nilai 86,7. 3 orang peserta didik ini berkode sampel 23, 30 dan 37.

\section{Simpulan dan Saran}

a. Kemampuan mengingat dan mengenali fakta tersurat isi bacaan, tergolong baik.

b. Kemampuan menginterpretasikan makna tersirat isi bacaan, tergolong cukup.

c. Kemampuan mengaplikasikan konsep isi bacaan, tergolong baik. 
d. Kemampuan menganalisis isi bacaan, tergolong baik.

e. Kemampuan menyintesis isi bacaan, tergolong baik.

f. Kemampuan menilai isi bacaan, tergolong cukup.

g. Kemampuan membaca kritis secara komprehensif, peserta didik memperoleh nilai rata-rata 70,10 dengan

\section{Daftar Rujukan}

Afdila. 2012. "Pengaruh Strategi SQ3R Terhadap Kemampuan Membaca Kritis Siswa Kelas VII SMP Negeri 3 Malang".

Publikasi Daring. (http://jurnalonline.um.ac.id/data/artikel.pdf) diakses 27 Agustus 2018.

Agustina. 2008. Pembelajaran Keterampilan Membaca. Padang: FBSS UNP.

Arikunto, Suharsimi. 1999. Dasar-dasar Evaluasi Pendidikan (Edisi Revisi). Jakarta: Bumi Aksara.

Ghazali, A. Syukur. 2010. Pembelajaran Kemampuan Berbahasa. Malang: PT Refika Aditama.

Junining, Esti. 2015. Membaca Kritis Membaca Kreatif (Panduan Praktis Bagaimana Cara Membaca Kritis untuk Semua Kalangan).

Lestari, Oktavia P. 2017. "Pengaruh Teknik Membaca Formula 5S Terhadap Kemampuan Membaca Kritis Siswa Kelas VIII SMP Muhammadiyah 1 Medan Tahun Pembelajaran 2016/2017”. Jurnal Publikasi Daring. (http://garuda.ristekdikti.go.id) diakses 4 Agustus 2018.

Nurhadi. 2010a. Bagaimana Meningkatkan Kemampuan Membaca. Bandung: Sinar baru Algensindo. kategori baik dan berada pada interval penguasaan 66-79.

Saran Pertama, bagi peserta didik, SMP Negeri 15 Banjarmasin sebaiknya menambah pengetahuan tentang konsep membaca, khususnya membaca kritis terlebih pada aspek menginterpretasikan makna tersirat dan menilai isi bacaan. Untuk Guru mengajarkan bagaimana menjadi pembaca yang baik.

Nurhadi. 2010b. Membaca Cepat dan Efektif. Bandung: Sinar Baru Algensindo.

Saepudin, Encang. 2015. "Tingkat Budaya Membaca Masyarakat". Jurnal Publikasi Daring. (https://scholar.google.co.id) diakses 6 Agustus 2018.

Soehardi, Sigit. 2003. Esensi Perilaku Organisasional. Yogyakarta: BPFE UST.

Sugiyono. 2016. Metode Penelitian Kuantitatif Kualitatif dan $R \& D$. Bandung: Alfabeta.Tarigan, Henry Guntur. 2015. Membaca Sebagai Suatu Keterampilan Berbahasa. Bandung: Angkasa.

Umairi, Junaina. 2013. "Kemampuan Menulis Kembali Isi Cerpen Sepotong Burger Karya Sanice oleh Siswa Kelas IX SMP N 1 Sei Kanan Labuhan Batu Selatan Tahun Pembelajaran 2012/2013”. Jurnal Publikasi Daring. (https://jurnal.unimed.ac.id/2012/) diakses 8 Agustus 2018. 